\title{
Wymagania i perspektywy rozwoju jakości olejów napędowych przeznaczonych do eksploatacji szczególnie w warunkach komunikacji miejskiej z uwzględnieniem ochrony środowiska
}

\begin{abstract}
Wprowadzenie
Oleje napędowe są to mieszaniny ciekłych węglowodorów o temperaturach wrzenia w zakresie $180 \ldots .380^{\circ} \mathrm{C}$, uszlachetnione dodatkami, stosowane jako paliwa do silników o zapłonie samoczynnym. Oleje napędowe otrzymywane są przez odpowiednie komponowanie produktów $z$ destylacji ropy naftowej oraz innych procesów rafineryjnych [1].

Oleje napędowe stosowane współcześnie, różnicowane są głównie wartościami temperatury zablokowania zimnego filtra (CFPP), temperatury krzepnięcia oraz lepkości. Wśród wielu użytkowników pokutuje pogląd o pozostałościowym charakterze olejów napędowych. Oleje te zwane potocznie i nieprawidłowo "ropą" uznawane są przez tych użytkowników za paliwa gorszej jakości, w stosunku do których stawiane są niskie wymagania co do sposobu produkcji, przechowywania i eksploatacji. Panuje również przekonanie, że większość stosowanych w eksploatacji silników wysokoprężnych może być zasilana nisko jakościowymi paliwami za jakie się uznaje oleje napędowe, a zatem pomijane są w takim podejściu wymuszenia występujące we współcześnie produkowanych silnikach, a także złożony współczesnymi wymaganiami jakościowymi proces otrzymywania olejów, jak również zaostrzające się wymagania z zakresu ochrony środowiska, co ma szczególne znaczenie w warunkach ich eksploatacji w komunikacji miejskiej.

Współczesne oleje napędowe stanowią paliwa o ostrych wymaganiach jakościowych oznaczanych coraz bardziej wyrafinowanymi metodami badań. Ze względu na radykalne zmiany w konstrukcjach silników spalinowych o zapłonie samoczynnym i wzrostem wymuszeń w stosunku do sto-
\end{abstract}

Szkoła Główna Służby Pożarniczej w Warszawie. 
sowanych w nich płynach eksploatacyjnych wzrastają wymagania jakościowe na oleje napędowe. Wymagania te dość istotnie związane są nie tylko z budową układów zasilania i spalania silników, ale także z zaostrzającymi się wymaganiami z zakresu ochrony środowiska naturalnego.

\section{Wymagania w zakresie właściwości niskotemperaturowych olejów napędowych}

Właściwości reologiczne olejów napędowych, szczególnie w obniżonych temperaturach, mają bardzo istotny wpływ na pracę układów zasilania i spalania w silnikach wysokoprężnych. Determninują one możliwości dostarczania dostatecznych porcji oleju do komory spalania, co ma szczególne znaczenie podczas rozruchu, w niskich temperaturach otoczenia. $W$ temperaturach tych niektóre składniki zawarte $\mathrm{w}$ olejach napędowych mogą ulegać częściowej krystalizacji. W stosunkowo najwyższych temperaturach krystalizują, pożądane w olejach napędowych ze względu na właściwości samozapłonowe, węglowodory parafinowe.

Krystalizujące węglowodory, zatykając przegrody filtracyjne filtrów dokładnego oczyszczania powodują powstawanie znacznych oporów hydraulicznych, przez co maleje wydatek paliwa. Proces narastania zjawiska krystalizacji może doprowadzić do całkowitego zablokowania przepływu paliwa przez filtr, co ma z zasady miejsce wtedy, gdy na filtrze osadzi się warstewka krystaliczna o grubości powyżej $3 \mathrm{~mm}$. Temperatura, w której zachodzi to zjawisko jest bardzo ważnym kryterium dopuszczającym oleje napędowe do eksploatacji i nosi nazwę temperatury zablokowania zimnego filtru, zwaną także krytyczną temperaturą filtrowalności lub oznaczana skrótowo jako CFPP ("cold filter plugging point"). Pomiaru CFPP dokonuje się metodą Hagenmanna i Hammericha, mierząc najwyższą temperaturę, w której ustanie przepływ badanego oleju przez znormalizowany układ filtracyjny i w znormalizowanych warunkach, lub przepływ $20 \mathrm{~cm}^{3}$ badanego oleju przez ten układ będzie dłuższy od $60 \mathrm{~s}$. Temperatura zablokowania zimnego filtra jest wyższa o około $10 \ldots 15^{\circ} \mathrm{C}$ od temperatury krzepnięcia oleju napędowego rozumianej jako temperatura przy której nastąpi utrata ruchliwości próbki oleju w taki sposób, aby menisk produktu w próbówce, przechylonej o kąt $45^{\circ}$ nie zmienił położenia w czasie krótszym od $60 \mathrm{~s}$. Powyżej temperatury krzepnięcia, znajduje się określana $w$ normach przedmiotowych temperatura mętnienia olejów napędowych. Czasami spotyka się również podawanie w źródłach wartości temperatury krystalizacji. Obie te temperatury charakteryzują to samo zjawisko fizyczne, jednak inaczej wizualizowane. $W$ przypadku pomiaru temperatury mętnienia, obserwowane jest zmętnienie znormalizowanej próbki, a w przypadku pomiaru temperatury krystali- 
zacji, wydzielanie z próbki podczas ochładzania, widocznych nieuzbrojonym okiem pojedynczych kryształów.

$\mathrm{Na}$ wartości wymienionych temperatur, szczególnie CFPP, istotny wplyw, poza składem frakcyjnym, ma stopień zanieczyszczenia i zawodnienia paliwa oraz okres jego przechowywania w zbiornikach magazynowych. Zanieczyszczenia mechaniczne osiadając na filtrach, przyspieszają ich zablokowanie, a jednocześnie wokół mikrocząstek pyłów i zanieczyszczeń łatwiej mogą krystalizować węglowodory parafinowe. Zawartość wody znacznie pogarsza właściwości niskotemperaturowe olejów napędowych, natomiast $w$ długim okresie przechowywania olejów napędowych, wytwarzać w nich się mogą żywiczne produkty starzenia, które zaburzają przepływ paliwa przez filtr i przyspieszają jego krystalizację.

Właściwości niskotemperaturowe olejów napędowych maja istotne znaczenie dla komunikacji miejskiej, podczas rozruchów zimnych silników, przy porannym uruchamianiu parku autobusowego, szczególnie $w$ warunkach zimowych. Niewłaściwie dobrane lub złej jakości oleje napędowe, stosowane $w$ tych warunkach moga nie pozwolić na uruchomienie silników, bez stosowania zewnętrznych systemów rozruchowych lub podgrzewaczy paliwa, a także zmuszać kierowców do utrzymywania silników na biegu jałowym podczas dłuższych postojów na przystankach końcowych, co powodować może nadmierne zużycie paliwa.

Współczesne wymagania europejskie, dla klimatu umiarkowanego, w zależności od gatunku oleju, dopuszczaja wartości CFPP od $5^{\circ} \mathrm{C}$ max. dla gatunku "A" poprzez $0,-5,-10,-15^{\circ} \mathrm{C}$ dla kolejnych gatunków, kończąc na wartości max. $-20^{\circ} \mathrm{C}$ dla gatunku " $\mathrm{F}^{\prime}$. Dla tak zwanej grupy olejów arktycznych, wartości CFPP, dla klas od 0 do 4, wynoszą odpowiednio: $20,-26,-38,-44^{\circ} \mathrm{C}$, a tolerowane w normach wartości temperatur mętnienia są o $10^{\circ} \mathrm{C}$ wyższe dla każdej z klas.

Zestawienie różnic i tendencji zmian $w$ zakresie podstawowych właściwości niskotemperaturowych olejów napędowych przeznaczonych do eksploatacji w warunkach miejskich, w porównaniu $\mathrm{z}$ wymaganiami europejskimi przedstawiono $\mathrm{w}$ tablicy 1 . Oleje napędowe przeznaczone do warunków eksploatacji miejskiej, zostały nazwane olejami typu „ekologicznego" i w związku z tym do symboli olejów letniego, przejściowego i zimowego (DL,DP,DZ) wg. normy PN-92/C-96051, zgodnie z odpowiednią normą zakładową, została dodana litera „E”. Kolejna norma zakładowa wprowadziła do eksploatacji w Polsce tzw. "olej napędowy miejski” (ONM), produkowany w klasie "standard”, odpowiadający produkowanym w niektórych krajach europejskich olejom napędowym typu "City Diesel". 
Krzysztof Biernat

\begin{tabular}{|c|c|c|c|c|c|c|}
\hline Właściwość & \multicolumn{3}{|c|}{$\begin{array}{l}\text { Norma Zakładowa } \\
\text { ZN-93/MPiH/NF-209 }\end{array}$} & $\begin{array}{l}\text { Norma Zakładowa } \\
\text { ZN94/MPiHNF-213 }\end{array}$ & $\begin{array}{c}\text { Norma } \\
\text { Europejska }\end{array}$ & $\begin{array}{c}\text { Metoda } \\
\text { badań }\end{array}$ \\
\hline Typ oleju & EDL & EDP & EDZ & ONM „Standard”. & - & - \\
\hline $\begin{array}{l}\text { Temp. mętnienia } \\
w^{\circ} \mathrm{C} \text { max. }\end{array}$ & \multicolumn{3}{|c|}{$\begin{array}{l}\text { nie normalizuje się, } \\
\text { podawać w atestach }\end{array}$} & -25 & - & - \\
\hline $\begin{array}{c}\text { CFPP } w^{\circ} \mathrm{C} \text { max. } \\
\text { dla gatunku A } \\
\text { gatunku B } \\
\text { gatunku C } \\
\text { gatunku D } \\
\text { gatunku } \mathrm{E} \\
\text { gatunku } \mathrm{F}\end{array}$ & 0 & -15 & -20 & -30 & $\begin{array}{c}- \\
5 \\
0 \\
-5 \\
-10 \\
-15 \\
-20\end{array}$ & EN 116 \\
\hline
\end{tabular}

Tablica 1. Zestawienie różnic i tendencji zmian w zakresie właściwości niskotemperaturowych olejów napędowych eksploatowanych w umiarkowanej strefie klimatycznej

Wymagania Polskiej Normy w zakresie właściwości podanej w tablicy, obowiązującej od 1999r, pokrywają się z wymaganiami aktualnej Normy Europejskiej. Olej EDP ma obniżony o $3^{\circ} \mathrm{C}$ CFPP w stosunku do oleju DP. Wartość CFPP dla oleju ONM odpowiada wartości tej temperatury przyjętej w wymaganiach polskiej Normy Obronnej NO-91-A219.

W tablicy 2, przedstawiono aktualne wymagania normy europejskiej, w zakresie podstawowych właściwości niskotemperaturowych olejów napędowych przeznaczonych do eksploatacji w tak zwanych arktycznych warunkach klimatycznych.

\begin{tabular}{|c|c|c|c|c|c|c|}
\hline Właściwość: & \multicolumn{5}{|c|}{ Zakres } & Metoda badań \\
\hline Klasa oleju & 0 & 1 & 2 & 3 & 4 & - \\
\hline $\begin{array}{c}\text { Temp. krzepnięcia } \\
\mathrm{w}^{\circ} \mathrm{C} \text { max. }\end{array}$ & -10 & -16 & -22 & -28 & -34 & EN 23015 \\
\hline CFPP $w^{\circ} \mathrm{C}$ max. & -20 & -26 & 32 & -38 & -44 & EN 116 \\
\hline
\end{tabular}

Tablica 2. Właściwości niskotemperaturowe olejów napędowych przeznaczonych do ekspłoatacji w klimacie arktycznym według normy EN 590:2004

\section{Wymagania związane $z$ odparowaniem olejow napędowych}

Proces odparowania oleju napędowego $\mathrm{w}$ silniku o zapłonie samoczynnym można podzielić na dwa zasadnicze etapy [2].

Pierwszy $z$ tych etapów trwa od momentu rozpoczęcia wtrysku paliwa do momentu samozapłonu i odbywa się kosztem ciepła zawartego w komorze spalania sprężonego powietrza. W czasie trwania tego etapu ma 
miejsce wstępne utlenienie odparowujących węglowodorów, a ciepło egzotermicznych reakcji utleniania przyspiesza przebieg i intensywność procesu odparowania. Etap ten zwany jest również etapem zwłoki samozapłonu i jak dalej zostanie to określone, pokrywa się $w$ czasie $z$ pierwszym etapem spalania.

Drugi etap procesu odparowania trwa od momentu samozapłonu do zakończenia procesu wtrysku paliwa. Odparowanie paliwa, w tym przypadku odbywa się równocześnie $\mathrm{z}$ trwaniem procesu spalania, kosztem ciepła wydzielającego się $\mathrm{w}$ czasie spalania uprzednio odparowanych porcji paliwa.

W silnikach z komorami wstępnymi, odparowanie rozpoczyna się już od momentu podania paliwa przez wtryskiwacz do komory wstępnej. Powstająca w niej mieszanka bogata, swoim składem mieści się w granicach zapłonu. Przy odpowiednio wysokiej temperaturze mieszanka ta ulega samozapłonowi i częściowemu spaleniu. Część nieodparowanego paliwa, gwałtownie parując, podwyższa ciśnienie, które powoduje wtłoczenie palącej się mieszanki do komory głównej, gdzie trwa dalej rozpoczęty proces spalania paliwa.

$\mathrm{Na}$ sposób doprowadzenia i odparowania paliwa istotny wpływ ma lepkość oleju napędowego. Przy $20^{\circ} \mathrm{C}$ lepkość olejów napędowych do szybkoobrotowych silników wysokoprężnych zawiera się na ogół w granicach $2,8 \ldots 8,0 \mathrm{~mm}^{2} / \mathrm{s}$.

Dla każdego rodzaju silnika istnieje ograniczona lepkość paliwa, która przy danej konstrukcji układu zasilania uniemożliwia rozwinięcie normalnej mocy na skutek zbyt dużych oporów hydraulicznych i zakłóceń w zasilaniu. Ponieważ lepkość olejów napędowych maleje wraz ze wzrostem temperatury to poprzez temperaturowe zmiany lepkości zmieniają się warunki przetłaczania tych olejów. Najmniejsze zmiany lepkości wraz ze zmianami temperatury wykazują frakcje parafinowe zawarte w olejach. Nadmiar tych frakcji, polepszając właściwości samozopłonowe pogarsza znacznie wlaściwości niskotemperaturowe, podwyższając temperatury mętnienia i krzepnięcia oraz temperaturę blokady zimnego filtra.

W miarę podwyższania lepkości oleju zmniejsza się stopień rozpylania i odparowania strumienia paliwa, natomiast zwiększa się zasięg strumienia i paliwo może osadzać się na denkach tłoka i ściankach komory spalania tworząc nagary. Zbyt mała lepkość pogarsza warunki smarowania tłoczków pompy wtryskowej oraz zmniejsza zasięg strumienia, powodując nierównomierne rozłożenie kropel paliwa w komorze spalania i doprowadzając do spalania niezupełnego oraz miejscowego przegrzewania ścianek komory spalania. Mała lepkość paliwa może być również przyczyną wycieków paliwa z par precyzyjnych i jednocześnie zmniejszania dawki podawanego paliwa. 
Strumień paliwa podawany pompą wtryskową przez wtryskiwacze robocze składa się z kilku milionów kropel paliwa o średnicach od $3 . .5 \mathrm{~mm}$ do $100 \ldots 150 \mathrm{~mm}$. Jakość rozpylenia paliwa charakteryzowana jest ilością i wielkością kropel paliwa, a dokładniej stopniem rozpylenia i jednorodnością rozpylenia oraz zasięgiem strumienia i wielkością kąta stożka rozpylenia.

Przez stopień rozpylenia należy rozumieć przeciętny rozmiar kropel opuszczających wtryskiwacz, a przez jednorodność strumienia - stosunek ilości kropel paliwa o średnim rozmiarze do całkowitej ilości kropel.

$\mathrm{Na}$ jakość rozpylenia, oprócz konstrukcji dyszy wtryskiwacza, wpływają następujące właściwości olejów napędowych:

- lepkość (omówiona powyżej);

- gęstość;

- skład frakcyjny;

- prężność par;

- napięcie powierzchniowe;

- ciepło parowania paliwa;

- ciepło spalania paliwa.

Im większy jest stopień i jednorodność rozpylania, tym łatwiejsze jest odparowanie oleju napędowego. Podobnie jak lepkość, gęstość paliwa wpływa głównie na zasięg strumienia paliwa w komorze spalania. Niezależnie od tego, obniżenie gęstości oleju napędowego powoduje redukcję emisji cząstek stałych do przebiegu liniowego [3], a także w niektórych przypadkach może powodować obniżanie emisji tlenków azotu. Zmniejszanie gęstości oleju napędowego związane jest także ze spadkiem jego wartości opałowej, co ma istotny wpływ na osiągi silników. Powstrzymywanie obniżania się mocy silnika w tym przypadku poprzez zwiększanie dawki paliwa powoduje wzrost zużycia tego paliwa niwelujący obniżenie emisji cząstek stałych. Obniżenie gęstości może także powodować niewielkie redukcje emisji $\mathrm{CO}_{2}$, sięgające do $1 \%$. A zatem gęstość olejów napędowych powinna być odpowiednio niska i zmieniać się w niewielkich granicach. Aktualnie wymagania norm europejskich dopuszczają gęstość olejów napędowych w przedziale $820 \ldots 860 \mathrm{~kg} / \mathrm{m}^{3} \mathrm{w}$ temperaturze $15^{\circ} \mathrm{C}$, a przewidują po 2000 roku obniżenie górnej granicy gęstości do $845 \mathrm{~kg} / \mathrm{m}^{3}$.

Jednorodność rozpylenia paliwa jest wprost proporcjonalna do jego napięcia powierzchniowego, które zależy od obecności w cząsteczkach oleju połączeń polarnych. Wraz ze wzrostem gęstości paliwa, napięcie powierzchniowe rośnie i na granicy faz powietrze - olej napędowy waha się w granicach $27 \cdot 10^{-}$ ${ }^{7} . .30 \cdot 10^{-7} \mathrm{~J} / \mathrm{cm}^{2}$, malejąc wraz ze wzrostem temperatury, co stanowi proces korzystny dla procesu rozpylania paliwa. Węglowodory parafinowo - naftenowe zawarte $w$ olejach napędowych odznaczają się znacznie mniejszymi wartościami napięcia powierzchniowego niż węglowodory aromatyczne.

$\mathrm{Na}$ proces odparowania paliwa ma także wpływ jego skład frakcyjny, określany przy pomocy destylacji normalnej. Temperatura początku destyla- 
cji ma wpływ na właściwości rozruchowe silnika, natomiast wartość temperatury oddestylowania 50\%, korelując z lepkością i gęstością paliwa wpływa na stopień i jednorodność rozpylenia oraz na ustabilizowany przebieg procesów odparowania i spalania, a także na łatwość rozruchu, zapewniając tak zwaną jego ciągłość. Temperatury oddestylowania 90 i $95 \%$ oraz końca destylacji istotnie rzutują na emisję toksycznych składników spalin. Dyrektywa Unii Europejskiej z 1998 r. określała maksymalną temperaturę oddestylowania 95\% olejów napędowych na $370^{\circ} \mathrm{C}$, a od roku 1999 obowiązuje jej obniżenie do $360^{\circ} \mathrm{C}$. Szybkie odparowanie lekkich frakcji paliwa skraca czas niezbędny do wytworzenia jednorodnej mieszanki palnej. Z drugiej strony jednak narasta gwałtownie ciśnienie, po samozapłonie mieszanki powodując niekorzystną, twardą pracę silnika. Frakcje ciężkie zawarte w oleju napędowym mogą doprowadzać do niezupełnego spalania paliwa, powodując występowanie rozkładu termicznego nieodparowanych kropli z wydzieleniem dużych ilości sadzy w spalinach oraz osadzanie się nagarów na końcówkach wtryskiwaczy roboczych. Niespalone paliwo jednocześnie spływając po ściankach komory spalania może spowodować zmywanie oleju smarowego i przyspieszać zużycie tulei cylindrowych.

Wartość ciepła parowania paliwa, która jest cechą wprawdzie nie oznaczaną $w$ normach przedmiotowych, ale uwzględnianą $w$ procesie technologicznego odbioru frakcji olejów napędowych z kolumny destylacyjnej, wpływa na łatwość tworzenia się mieszanki palnej w momencie rozruchu zimnego silnika. Jak już wspomniano, właściwości te mogą także być określana przy pomocy temperatur początku destylacji i odparowania $50 \%$ frakcji oleju napędowego.

W tablicy 3 zestawiono różnice oraz tendencje zmian podstawowych właściwości olejów napędowych, istotnych dla procesu odparowania tych paliw.

\begin{tabular}{|c|c|c|c|c|c|c|c|}
\hline Właściwość: & \multicolumn{3}{|c|}{$\begin{array}{l}\text { Norma Zakładowa } \\
\text { ZN-93/MPiH/NF-209 }\end{array}$} & \multirow{2}{*}{\begin{tabular}{|c|}
$\begin{array}{c}\text { Norma } \\
\text { ZN-94 } \\
\text { MPiH/NF-213 }\end{array}$ \\
$\begin{array}{c}\text { ONM } \\
\text { Standard }\end{array}$ \\
\end{tabular}} & \multirow{2}{*}{\begin{tabular}{|c|}
$\begin{array}{c}\text { Norma } \\
\text { Europejska } \\
\text { EN 590: 2004 }\end{array}$ \\
-
\end{tabular}} & \multirow{2}{*}{\begin{tabular}{|c|}
$\begin{array}{c}\text { Metoda badań } \\
\text { wg. EN }\end{array}$ \\
-
\end{tabular}} & \multirow{2}{*}{$\begin{array}{c}\begin{array}{c}\text { Polska Norma } \\
\text { PN-EN } \\
\text { 590:1999 }\end{array} \\
-\end{array}$} \\
\hline Typ oleju & EDL & EDP & $E D Z$ & & & & \\
\hline Gęstość w $15^{\circ} \mathrm{C} w \mathrm{~kg} / \mathrm{m}^{3}$ & \multicolumn{3}{|c|}{$\begin{array}{c}810-860 \\
w 20^{\circ} \mathrm{C}\end{array}$} & $800 \cdot 830$ & $820-845$ & $\begin{array}{l}\text { EN ISO } 3675 \\
\text { EN ISO } 12185\end{array}$ & $\max .845$ \\
\hline Lepkość w $40^{\circ} \mathrm{C} \mathrm{w} \mathrm{mm} / \mathrm{s}$ & \multicolumn{2}{|c|}{$2,0-4,5$} & $1,8-4,0$ & $>1,50$ & $2,00-4,50$ & EN ISO 3104 & $2,00-4,50$ \\
\hline $\begin{array}{l}\text { Skład frakcyjny: } \\
5 \% \text { obj.dest do temp. }{ }^{\circ} \mathrm{C} \\
50 \% \text { obj.dest do temp. }{ }^{\circ} \mathrm{C} \\
\% \text { obj.dest.do } 250^{\circ} \mathrm{C} \text { max. } \\
95 \% \text { obj.dest do temp. }{ }^{\circ} \mathrm{C} \\
\text { \%obj.dest.do } 350^{\circ} \mathrm{C} \text { min. }\end{array}$ & $\begin{array}{c}- \\
300 \\
65 \\
- \\
85\end{array}$ & $\begin{array}{c}- \\
290 \\
65 \\
- \\
86\end{array}$ & $\begin{array}{c}- \\
280 \\
65 \\
- \\
90\end{array}$ & $\begin{array}{c}190 \\
240 \\
- \\
290 \\
-\end{array}$ & $\begin{array}{c}- \\
- \\
<65 \\
360 \\
85\end{array}$ & $\begin{array}{c}- \\
\text { 1SO } 3405 \\
- \\
\text { ISO } 3405\end{array}$ & $\begin{array}{c}- \\
- \\
<65 \\
360 \\
-\end{array}$ \\
\hline
\end{tabular}

Tablica 3. Zestawienie różnic i tendencji zmian podstawowych właściwości olejów napędowych, mających wpływ na proces odparowania, w umiarkowanym klimacie eksploatacji 
Według wymagań europejskich objętości oddestylowanego oleju napędowego są normowane dla olejów eksploatowanych w klimacie arktycznym dla temperatur $180^{\circ} \mathrm{C}$ i $340^{\circ} \mathrm{C}$, jak to pokazano w tablicy 4 .

\begin{tabular}{|c|c|c|c|c|c|c|}
\hline \multirow{2}{*}{$\begin{array}{c}\text { Właściwość: } \\
\text { Klasa oleju }\end{array}$} & \multicolumn{5}{|c|}{ Zakres } & \multirow{2}{*}{$\frac{\text { Metoda badań }}{-}$} \\
\hline & 0 & 1 & 2 & 3 & 4 & \\
\hline $\begin{array}{c}\text { Gęstość w } 15^{\circ} \mathrm{C} \\
w \mathrm{~kg} / \mathrm{m}^{3}\end{array}$ & \multicolumn{2}{|c|}{$800-845$} & \multicolumn{3}{|c|}{$800-840$} & $\begin{array}{l}\text { EN ISO } 3675 \\
\text { EN ISO } 12185\end{array}$ \\
\hline $\begin{array}{c}\text { Lepkośc w } 40^{\circ} \mathrm{C} \\
w \mathrm{~mm}^{2} / \mathrm{s}\end{array}$ & \multicolumn{3}{|c|}{$1,50-4,00$} & $1,40-4,00$ & $1,20-4,00$ & EN ISO 3104 \\
\hline $\begin{array}{c}\text { Skład frakcyjny: } \\
\text { \%obj.dest.do } 180^{\circ} \mathrm{C} \\
\text { max. } \\
\text { \%obj.dest.do } 340^{\circ} \mathrm{C} \\
\text { min. }\end{array}$ & \multicolumn{5}{|c|}{10} & ISO 3405 \\
\hline
\end{tabular}

Tablica 4. Właściwości olejów napędowych eksploatowanych w klimacie arktycznym, związane z procesem odparowania według wymagań normy EN 590:2004

\section{Wymagania związane z procesem spalania olejów napedowych}

Procesy spalania olejów napędowych zachodzące w silnikach o zapłonie samoczynnym przebiegają w trzech wydzielonych etapach.

Etap pierwszy procesu spalania jest okresem zwłoki samozapłonu, czyli okresem wstępnego utleniania paliwa. Rozpoczyna się on w momencie wtrysku paliwa występującym w przedziale $20 . .30^{\circ}$ obrotu wału korbowego (OWK) przed zwrotem zewnętrznym (ZZ) i trwa w czasie około 0,0007s, to znaczy do momentu samozapłonu. Etap ten pokrywa się $w$ całości $z$ pierwszym etapem odparowania paliwa. Im intensywniej zachodzą procesy wstępnego utleniania paliwa, które zachodzą tym szybciej im wyższa jest temperatura i ciśnienie panujące w komorze spalania, tym okres zwłoki samozapłonu jest krótszy, a praca silnika bardziej równomierna. Czas trwania pierwszego etapu spalania zależy przede wszystkim od składu chemicznego paliwa.

W drugim etapie procesu spalania, gwałtownemu spalaniu ulega nagromadzone $\mathrm{w}$ pierwszym etapie i przygotowane do spalania paliwo. Okres ten jest okresem szybkiego spalania i intensywnego przyrostu ciśnienia $w$ komorze spalania. Płomień powstaje $w$ licznych punktach komory spalania od poszczególnych ognisk samozapłonu, wytworzonych przez rodniki aktywne, a czas trwania tego etapu zależy od ilości odparowanego paliwa i równomierności jego wymieszania $\mathrm{z}$ powietrzem. Gwałtowne przyrosty ciśnienia w drugim etapie spalania mogą dać efekty porównywalne do spalania detonacyjnego $\mathrm{w}$ silnikach $\mathrm{z}$ zapłonem iskrowym. Czas trwania drugiego etapu spalania determinuje prace silni- 
ka wysokoprężnego. Przy krótkich zwłokach samozapłonu przyrosty ciśnienia sa stosunkowo łagodne i silnik pracuje „miękko”. Przy zbyt długich zwłokach samozapłonu dochodzić może do całego szeregu negatywnych zjawisk.

Gwałtowne przyrosty ciśnienia i temperatury doprowadzaja do osadzania się nadmiernych ilości nagaru powstającego na skutek rozkładu termicznego paliwa. Występować również może nadmierne obciążenie układu tłokowo - korbowodowego i łożysk, spada moc i zmniejsza się ekonomiczność pracy silnika. Powstająca sadza i inne gazowe produkty rozkładu paliwa znacznie zanieczyszczają spaliny i powodują wzrost ich zadymienia. Praca silnika jest określana jako „twarda" i słyszalne są metaliczne stuki w cylindrach.

Trzeci etap spalania jest okresem opóźnionego i kontrolowanego spalania. W tym etapie paliwo ulega szybkiemu odparowaniu i spala się $\mathrm{w}$ miarę podawania go przez wtryskiwacz, aż do zakończenia procesu wtrysku. Przy prawidłowej pracy silnika, jego nastawach i właściwie dobranym paliwie, szybkość narastania ciśnienia nie powinna przekraczać wartości około $588 \mathrm{kPa}$.

Ze składników zawartych w olejach napędowych najlepsze właściwości samozapłonowe wykazują długołańcuchowe węglowodory parafinowe. Stopien izomeryzacji tych węglowodorów wydłuża okres zwłoki samozapłonu. Węglowodory nienasycone, alkeny mają zwłoki samozapłonu zbliżone do odpowiednich parafin i izoparafin. Węglowodory naftenowe charakteryzuja się większą odpornością na utlenianie niż parafiny. Boczny łańcuch parafinowy, z zasady wydłuża zwłokę samozapłonu węglowodorów naftenowych.

Najdłuższymi zwłokami samozapłonu charakteryzują się węglowodory aromatyczne $i$ to tym większymi, im więcej pierścieni zawartych jest w cząsteczce. Wprowadzenie bocznego łańcucha skraca zwłokę samozapłonu aromatów, szczególnie przy nierozgałęzionych łańcuchach.

Generalnie można przyjąć, że czym wyższą temperaturą wrzenia charakteryzują się węglowodory wchodzące w skład olejów napędowych, tym te oleje mają lepsze właściwości samozapłonowe. Skłonność olejów napędowych do samozapłonu określana jest $\mathrm{w}$ normach za pomocą liczby cetanowej i indeksu cetanowego.

Liczba cetanowa [LC] olejów napędowych jest ich miarą skłonności do samozapłonu. Definiuje się ją jako liczbę całkowitą, niemianowaną wyrażajaca procent objętościowy paliwa wzorcowego n-cetan $\left(\mathrm{C}_{16} \mathrm{H}_{34}\right)$, o przyjętej umownie wartości liczby cetanowej jako 100 jednostek, zawarty $\mathrm{w}$ mieszaninie $\mathrm{z}$ paliwem wzorcowym a-metylonaftalen o przyjętej umownie wartości liczby cetanowej jrównej 0 jednostek, aby tak sporządzona mieszanina, w znormalizowanych warunkach i w znormalizowanym silniku spalała się $\mathrm{z}$ taką samą skłonnością do samozapłonu jak badane paliwo [4]. 
Pomiar LC jest pomiarem złożonym i może być realizowany przy pomocy specjalnych silników testowych, w zależności od ich nastaw, metodami opóźnionego zapłonu, gdy wtrysk paliwa ustalany jest na $10^{\circ} \mathrm{OWK}$ przed ZZ, a zmianą stopnia sprężania doprowadza się do samozapłonu $1^{\circ}$ OWK po ZZ lub też metodą synchronizacji zapłonu, analogicznie: wtrysk paliwa $13^{\circ} \mathrm{OWK}$ przed ZZ, samozapłon w ZZ.

Zbyt niskie wartości LC poniżej 45 jednostek prowadzą do pogorszenia warunków pracy silnika, polegających na wydłużeniu zwłoki samozapłonu. Wydłużenie to może spowodować wystąpienie nadmiernych przyrostów ciśnienia i temperatury w komorze spalania prowadzące do wystąpienia twardej pracy silnika, prowadzącej do jego przedwczesnego zużycia, z jednoczesnym utrudnianiem rozruchu zimnego silnika.

Spalanie paliw o wartościach LC powyżej 70 jednostek prowadzi także do pogorszenia się przebiegu procesu spalania na skutek niepełnego spalania paliwa, przy bardzo krótkim okresie zwłoki samozapłonu, prowadzącym do nadmiernego zadymienia spalin i nie ekonomicznej pracy silnika.

Aktualne wymagania europejskie określają dopuszczalną, minimalną wartość liczby cetanowej na 49 jednostek, dla paliw stosowanych w klimacie umiarkowanym, przewidujac jej zwiększenie po 2000 roku do 51 jednostek. Dla paliw eksploatowanych w klimacie arktycznym, minimalne wartości LC, zawarte w normie są nieco niższe, tym bardziej im wyższy jest numer klasy.

Ze względu na złożoność pomiaru LC, wprowadzono do standartów na oleje napędowe określanie indeksu cetanowego (CI, CCI). Wskaźnik ten charakteryzuje również właściwości samozapłonowe olejów napędowych, ale może być wyliczony ze znajomości gęstości tych paliw i ich przebiegu destylacji normalnej.

Według normy ASTM D976-80 wskaźnik CI można obliczyć:

$\mathrm{CI}=454,74-1641,416 \mathrm{D}+774 \mathrm{D}^{2}-0,554 \mathrm{~B}+97,803(\operatorname{lgB})^{2}$ gdzie:

- D - gęstość paliwa w temperaturze $15^{\circ} \mathrm{C}$;

- B - temperatura oddestylowania $50 \%$ obj. paliwa $w^{\circ} \mathrm{C}$.

Drugi, bardziej złożony sposób obliczania indeksu cetanowego (CCI), według ASTM D4737-87, wymaga określenia gęstości paliwa oraz temperatur oddestylowania 10, 50 i $90 \%$ objętościowych paliwa i jest obliczany z zależności:

$$
\begin{aligned}
& \mathrm{CCI}=45,2+(0,0892)\left(\mathrm{T}_{10 \mathrm{~N}}\right)+[0,13]+(0,901)(\mathrm{B})\left(\mathrm{T}_{50 \mathrm{~N}}\right)+[0,0523- \\
& (0,0420)(\mathrm{B})]\left[\mathrm{T}_{90 \mathrm{~N}}\right]+ \\
& +[0,00049]\left[\left(\mathrm{T}_{10 \mathrm{~N}}\right)^{2}-\left(\mathrm{T}_{90 \mathrm{~N}}\right)^{2}\right]+(107)(\mathrm{B})+(60)(\mathrm{B})^{2} \text { gdzie: }
\end{aligned}
$$


- $B=\left[\mathrm{e}^{(-3,5)(\mathrm{DN})}\right]-1$;

- DN=D-0,85;

- D - gęstość paliwa w $15^{\circ} \mathrm{C}$;

- $\mathrm{T}_{10}$ - temperatura oddestylowania $10 \%$ obj. paliwa $\mathrm{w}^{\circ} \mathrm{C}$;

$-\mathrm{T}_{10 \mathrm{~N}}=\mathrm{T}_{10}-215$;

- $\mathrm{T}_{50}$ - temperatura oddestylowania $50 \%$ obj. paliwa $\mathrm{w}^{\circ} \mathrm{C}$;

$-\mathrm{T}_{50 \mathrm{~N}}=\mathrm{T}_{50}-260$;

- $\mathrm{T}_{90}$ - temperatura oddestylowania $90 \%$ obj. paliwa $\mathrm{w}^{\circ} \mathrm{C}$;

- $\mathrm{T}_{90 \mathrm{~N}}=\mathrm{T}_{90}-310$.

Ten drugi sposób obliczania indeksu cetanowego (CCI) jest aktualnie przyjmowany jako obowiązujący w normach. Wartość indeksu cetanowego różni się o 1...4 jednostki od LC, przyjmując wartości zazwyczaj niższe. Minimalna wartość indeksu cetanowgo dla olejów eksploatowanych w strefie umiarkowanej klimatycznie określana jest na 46 jednostek.

W normach przedmiotowych określana jest także wartość temperatury zapłonu olejów napędowych. Według wymagań europejskich, jej wartość minimalna powinna wynosić powyżej $55^{\circ} \mathrm{C}$ i jest ona wspólna, zarówno dla olejów eksploatowanych w klimacie umiarkowanym, jak i tez arktycznym.

Zestawienie podstawowych wymagań z zakresu przebiegu procesu spalania, dla olejów napędowych eksploatowanych w klimacie umiarkowanym i arktycznym przedstawiono odpowiednio w tablicach 5 i 6 .

\begin{tabular}{|c|c|c|c|c|c|c|c|}
\hline Wraściwośc: & \multicolumn{2}{|c|}{$\begin{array}{c}\text { Norma Zakładowa } \\
\text { ZN-93/MPiH /NF-209 }\end{array}$} & $\begin{array}{c}\text { Norma Zakład. } \\
\text { ZN-94/MPiH/ } \\
\text { NF-213 }\end{array}$ & $\begin{array}{c}\text { Norma } \\
\text { Europejska } \\
\text { EN 590: 2004 }\end{array}$ & $\begin{array}{c}\text { Metoda } \\
\text { badań } \\
\text { wg. EN }\end{array}$ & $\begin{array}{c}\text { Polska Norma } \\
\text { PN-EN 590:1999 }\end{array}$ \\
\hline Typ oleju & EDL & EDP & EDZ & ONM „Standard” & - & - & - \\
\hline Temp. zapłonu w ${ }^{\circ} \mathrm{C}$ min. & \multicolumn{2}{|c|}{45} & 55 & $>55$ & EN 22719 & - \\
\hline Liczba cetanowa min. & \multicolumn{2}{|c|}{49} & 50 & 51,0 & EN ISO 4264 & 51 \\
\hline Indeks cetanowy min. & \multicolumn{2}{|c|}{46} & 45 & 48 & 46,0 & EN ISO 4264 & 46,0 \\
\hline
\end{tabular}

Tablica 5. Zestawienie różnic i tendencje zmian podstawowych właściwości olejów napędowych mających wpływ na przebieg procesu spalania, eksploatowanych w umiarkowanych warunkach klimatycznych

\begin{tabular}{|c|c|c|c|c|c|c|}
\hline Właściwość: & \multicolumn{5}{|c|}{ Zakres } & Metoda badań \\
\hline Klasa oleju & 0 & 1 & 2 & 3 & 4 & - \\
\hline Temp.zaplonu ${ }^{\circ} \mathrm{C}$ & \multicolumn{5}{|c|}{$>55$} & EN 22719 \\
\hline Liczba cetanowa min & \multicolumn{3}{|c|}{49,0} & \multicolumn{2}{|c|}{47.0} & EN ISO 5165 \\
\hline Indeks cetanowy min & \multicolumn{3}{|c|}{46,0} & \multicolumn{2}{|c|}{43,0} & EN ISO 4264 \\
\hline
\end{tabular}

Tablica 6. Właściwości olejów napędowych eksploatowanych w klimacie arktycznym, związane z procesem spalania, według wymagań normy EN 590:2004 
Jak wynika $\mathrm{z}$ danych przytoczonych $\mathrm{w}$ tablicy 5, podstawowe parametry jakościowe oleju ONM "Standard”, wpływające na przebieg procesu spalania, mieszczą się w zakresie wymagań obowiązującej Normy Europejskiej, przewyższając wymagania aktualnej Normy Obronnej na olej napędowy F-9054-PL, dopuszczony do eksploatacji w Silach Zbrojnych RP.

Od 1994 roku, Petrochemia S.A. uruchomiła produkcję lekkiego oleju napędowego Ekodiesel. Dla tego gatunku oleju, podwyższona została minimalna wartość liczby cetanowej o cztery jednostki, w stosunku do dotychczas produkowanych w Polsce olejów napędowych.

\section{Wymagania stawiane olejom napędowym z zakresu korozji i ochrony środowiska}

Oprócz omówionych w poprzednich rozdziałach korelacjach pomiędzy właściwościami normatywnymi olejów napędowych, a oddziaływaniem procesu eksploatacji tych olejów na środowisko, niezmiernie ważna jest obecność siarki $w$ tych paliwach oraz zawartość węglowodorów aromatycznych.

Zawarta w olejach napędowych siarka i jej związki, których usuwanie w procesie produkcji tych paliw jest procesem złożonym, moga bezpośrednio działać korodująco na materiały konstrukcyjne silników w myśl reakcji:

$$
\begin{aligned}
& \mathrm{n}(\mathrm{R}-\mathrm{SH})+\mathrm{Me} \rightarrow(\mathrm{R}-\mathrm{S})_{\mathrm{n}}+\mathrm{nH}_{2} ; \\
& \mathrm{n}\left(\mathrm{H}_{2} \mathrm{~S}\right)+\mathrm{Me} \rightarrow \mathrm{n}(\mathrm{MeS})+\mathrm{nH}_{2^{\prime}} \\
& \mathrm{nS}+\mathrm{Me} \rightarrow \mathrm{n}(\mathrm{MeS}) .
\end{aligned}
$$

Oddziaływanie korodujace siarki elementarnej zaobserwowano już przy stężeniu $1 \mathrm{mg}$ na $100 \mathrm{ml}$ paliwa.

W procesie spalania olejów, zawarta w nich siarka utlenia się do tritlenku i ditlenku siarki, które łącząc się z parą wodną dają odpowiednio roztwory kwasów siarkowego (VI) (tetraoksosiarkowego) i siarkowego (IV) (trioksosiarkowego), działające silnie korozyjnie i zakwaszające wraz ze spalinami środowisko naturalne. Pewna część siarki w ilości $1 . .2 \%$ reaguje do postaci nierozpuszczalnych siarczanów emitowanych $\mathrm{w}$ postaci cząstek stałych wraz ze spalinami, co może być intensywne w przypadku pojazdów wyposażonych w katalizatory utleniające. Siarka działa również destrukcyjnie na katalizatory redukujące, czego efektem może być pogorszenie konwersji $\mathrm{NO}_{x}$ do $\mathrm{N}_{2}$.

Dyrektywa 98/70/EC dopuszczała zawartość siarki do 350 ppm, po 2000 roku, przewidując jej zmniejszenie do $50 \mathrm{ppm}$ po 2005 roku i dalej do 10 ppm.. 
Zawarte $w$ olejach napędowych węglowodory aromatyczne, niezależnie od pogorszenia właściwości samozapłonowych tych paliw, wpływaja negatywnie na zwiększenie emisji cząstek stałych, zmniejszenie redukcji emisji tlenków azotu oraz bezpośrednie zanieczyszczanie środowiska emisją toksycznych, kancerogennych węglowodorów, szczególnie wielopierścieniowych (WWA). Aktualnie zawartość WWA nie jest limitowana normami europejskimi, lecz po roku 2000 przewidziano jej ograniczenie normą do poziomu maksymalnego $11 \%$ mas, co jest standardem w obowiązującej normie EN.

W tablicy 7 przedstawiono podstawowe wymagania $\mathrm{i}$ tendencje zmian właściwości olejów napędowych mających wpływ na korozję oraz ochronę środowiska naturalnego. Właściwości te są lub będą normatywne dla wszystkich gatunków olejów napędowych, bez względu na klimatyczne warunki ich eksploatacji.

\begin{tabular}{|c|c|c|c|c|c|c|c|}
\hline \multirow{2}{*}{$\frac{\text { Właściwośc: }}{\text { Typ oleju }}$} & \multicolumn{3}{|c|}{$\begin{array}{l}\text { Norma Zakładowa } \\
\text { ZN-93/MPiH/ NF-209 }\end{array}$} & \multirow{2}{*}{$\begin{array}{c}\begin{array}{c}\text { Norma } \\
\text { Zakładowa } \\
\text { ZN-94/ } \\
\text { MPiH/NF-213 }\end{array} \\
\begin{array}{c}\text { ONM } \\
\text { "Standard" }\end{array}\end{array}$} & \multirow{2}{*}{$\begin{array}{c}\begin{array}{c}\text { Norma } \\
\text { Europejska } \\
\text { EN 590: 2004 }\end{array} \\
-\end{array}$} & \multirow{2}{*}{$\begin{array}{l}\begin{array}{c}\text { Metoda badań } \\
\text { wg. EN }\end{array} \\
\text { - }\end{array}$} & \multirow{2}{*}{ 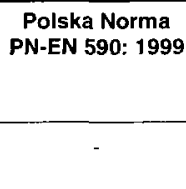 } \\
\hline & EDL & EDP & EDZ & & & & \\
\hline $\begin{array}{c}\text { Zawartość siarki } \\
\mathrm{mg} / \mathrm{kg}\end{array}$ & \multicolumn{3}{|c|}{$\begin{array}{c}0,20 \\
\% \operatorname{mas} \text {. max }\end{array}$} & 200 & $\begin{array}{c}\text { od } 01.01 .05 \\
50,0 \\
\text { od } 01.01 .09 \\
10,0\end{array}$ & $\begin{array}{l}\text { EN ISO20846 } \\
\text { EN ISO20847 } \\
\text { EN ISO20884 } \\
\text { EN ISO20846 } \\
\text { EN ISO20884 }\end{array}$ & 350 \\
\hline $\begin{array}{l}\text { Dziatanie korodujace na } \\
\text { phytce Cu w czasie } 3 \mathrm{~h}, \mathrm{w} \\
\text { temp } 50^{\circ} \mathrm{C} \text { w stop.korozji }\end{array}$ & \multicolumn{3}{|c|}{1} & 1 & 1 & EN ISO 2160 & 1 \\
\hline $\begin{array}{c}\text { Zawartośc WWA w \%mas } \\
\max \end{array}$ & \multicolumn{3}{|c|}{ - } & 22 & 11 & - & 11 \\
\hline
\end{tabular}

Tablica 7. Zestawienie różnic i tendencje zmian podstawowych wlaściwości olejów napędowych mających wpływ na procesy korozji i zagrożenie środowiska naturalnego

W 1998 roku Petrochemia S.A. w Płocku rozpoczęła produkcję nowej odmiany lekkiego oleju napędowego Ekodiesel Plus. W stosunku do poprzedniej wersji tego oleju, obniżona została zawartość siarki z $0,20 \%$ mas. do 0,050 \% mas. Spowodowało to konieczność wprowadzenia specjalnego dodatku podwyższającego smarność oleju, ponieważ własności smarnościowe, na skutek radykalnego obniżenia zawartości związków zawierających siarkę, uległy znacznemu pogorszeniu. Jednocześnie $w$ tym oleju poprawiono skład $w$ taki sposób, aby uległa zmniejszeniu emisja toksycznych składników spalin oraz zmniejszyły się skłonności paliwa do zanieczyszczania dyszy wtryskiwaczy roboczych. Jak wynika z tablicy 7, dla oleju ONM „Standard”, wprowadzono do normy konieczność ozna- 
czania zawartości WWA. Konieczność oznaczania tego parametru, zgodnie z Dyrektywą 98/70 EC obowiązuje od 2000 roku, ale jego dopuszczalna, górna granica nie będzie mogła przekraczać $11 \%$ mas. to znaczy dwa razy mniej niż obecnie dopuszcza się w oleju ONM.

\section{Pozostałe wymagania stawiane olejom napędowym, ze względu na ich właściwości eksploatacyjne}

Istnieje grupa właściwości olejów napędowych, charakteryzowanych w odpowiednich normach, które mają pośredni wpływ na wszystkie parametry procesu eksploatacji. Wpływają one istotnie na przebiegi procesów odparowania i spalania, a także na zagrożenia dla środowiska naturalnego oraz magazynowanie tych paliw. Do tych właściwości należą;

- zawartość wody;

- zawartość zanieczyszczeń stałych;

- pozostałość po spopieleniu;

- pozostałość po koksowaniu z 10\% pozostałości destylacyjnej;

- odporność na utlenianie;

- zawartość estrów metylowych kwasów tłuszczowych (biokomponentów - „FAME”);

- smarność.

Ta ostatnia cecha została wprowadzona do EN 590 w 1998 roku. Zasadność oznaczania smarności olejów napędowych wynika z konieczności zagwarantowania, szczególnie parom precyzyjnym w układzie zasilania, ochrony przed nadmiernym zużywaniem, tym bardziej, że znacznemu ograniczaniu podlega zawartość siarki w olejach. Niektóre związki siarki charakteryzują się bowiem dosyć dobrymi właściwościami przeciwzużyciowymi. Nowoczesne konstrukcje silników wysokoprężnych cechują się niewielkimi tolerancjami, bardzo wysoką dokładnością obróbki elementów oraz ciągle modyfikowanymi strukturami materiałów konstrukcyjnych. Przewiduje się, według CEC, że zużycie paliwa w tych silnikach po 2005 roku wynosić będzie średnio 4,51 na $100 \mathrm{~km}$, a po 2007 roku 2,51 na $100 \mathrm{~km}$.

Wpływ pozostałych, wymienionych powyżej właściwości olejów napędowych na podstawowe parametry pracy silnika i toksyczność spalin został już po części omówiony w poprzednich punktach opracowania. Zawartość wody i zanieczyszczeń mechanicznych zaburza proces transportu i dystrybucji paliwa w układzie zasilania, a w temperaturach bliskich $0^{\circ} \mathrm{C}$, przyspiesza procesy mętnienia (krystalizacji), krzepnięcia paliw i podwyższa CFPP.

Odporność na utlenianie jest właściwością, która określać może dopuszczalne czasy magazynowania olejów napędowych, ale także wpły- 
wać na przebieg procesu spalania tych paliw. Zbyt wysokie odporności na utlenianie wydłużają wprawdzie dopuszczalne czasy przechowywania olejów napędowych, jednak powodując jednocześnie pogorszenie procesu spalania, poprzez między innymi, wydłużenie okresu zwłoki samozapłonu, co może doprowadzać do twardej pracy silnika wraz z jej negatywnymi, dalszymi skutkami. Należy sądzić, że wartość odporności na utlenianie określona $\mathrm{w}$ obowiązującej normie europejskiej w najbliższym czasie nie będzie podlegać istotnym zmianom, o ile zmianie nie ulegnie norma na metodę badań.

Liczba koksowania olejów napędowych, określana z 10\% pozostałości podestylacyjnej jest miarą skłonności tych paliw do tworzenia nagarów. Zjawisko to powodować może zmiany warunków termicznych panujących w komorze spalania i pogorszenie przebiegu procesu spalania, powstawanie miejscowych gradientów temperatur, a w konsekwencji także dużych naprężeń $w$ materiałach konstrukcyjnych. Wraz z pozostałością po spopieleniu, może informować o możliwości emisji cząstek stałych wraz ze spalinami. Emisja ta, zgodnie z wymaganiami odpowiednich Agencji Ochrony Środowiska (EPA) będzie coraz bardziej ograniczana. Jej wielkość zależy także od rodzaju i ilości dodatków uszlachetniających wprowadzanych do olejów napędowych. W pracy [5] zawarte są dane dotyczące testów silnikowych i ich wyników w zakresie badania wpływu osadów pochodzących $\mathrm{z}$ dodatków na parametry pracy silników.

Graniczna wartość liczby koksowania, podana w normie europejskiej, winna być utrzymana przez producentôw paliw, przed ewentualnym dodaniem dodatków podwyższających LC. Jeżeli natomiast $w$ handlowym produkcie zostanie stwierdzona obecność dodatku podwyższającego LC, poprzez badanie według normy EN ISO 13759 na obecność dodatków zawierających azotany, to graniczna wartość liczby koksowania podana w normie przedmiotowej nie jest obowiązująca.

Z istotnych właściwości do oceny jakości i procesu eksploatacji olejów napędowych, aktualne normy nie przewidują konieczności oznaczania skłonności tych paliw do pienienia. Stosowane aktualnie w wielu krajach świata dodatki przeciwpienne do paliw oparte na bazach silikonowych, nie są dopuszczone do eksploatacji przez EPA w USA. Właściwości przeciwpienne olejów napędowych mają istotne znaczenie w procesie magazynowania, dystrybucji i procesach zasilania silników. Przedstawione w [5] testy laboratoryjne i silnikowe w zakresie oceny właściwości przeciwpiennych olejów napędowych, ich korelacje i wpływ na niektóre parametry eksploatacyjne pojazdów, sugerują o potrzebie włączenia tego kryterium do oceny jakości tych paliw.

W tablicy 8 przedstawiono porównanie ogólnych właściwości olejów napędowych przeznaczonych dla komunikacji miejskiej, w obowiązujących w Polsce normach, z aktualnie obowiązującą normą europejską. 
Krzysztof Biernat

\begin{tabular}{|c|c|c|c|c|c|c|}
\hline \multirow{2}{*}{$\begin{array}{l}\text { Właściwość } \\
\text { Typ oleju }\end{array}$} & \multicolumn{3}{|c|}{$\begin{array}{l}\text { Norma Zakładowa } \\
\text { ZN-93/MPiH/ NF-209 }\end{array}$} & \multirow{2}{*}{\begin{tabular}{|c} 
Norma Zaklad. \\
ZN-94/MPiH/NF-213 \\
ONM .Standard"
\end{tabular}} & \multirow{2}{*}{$\begin{array}{c}\begin{array}{c}\text { Norma } \\
\text { Europejska } \\
\text { EN 590: } 2004\end{array} \\
-\end{array}$} & \multirow{2}{*}{$\begin{array}{c}\text { Polska } \\
\text { Norma PN-EN } \\
\text { 590: 1999 } \\
-\end{array}$} \\
\hline & EDL & EDP & EDZ & & & \\
\hline $\begin{array}{c}\text { Pozostałość po koksowaniu } \\
\text { (z 10\% pozost.dest) \% mas.max. }\end{array}$ & \multicolumn{3}{|c|}{0,20} & 0,1 & 0,30 & 0,30 \\
\hline $\begin{array}{l}\text { Pozostałość po spopieleniu } \\
\text { \%mas.max. }\end{array}$ & \multicolumn{3}{|c|}{0.01} & 0,01 & 0,01 & 0,01 \\
\hline Zawartość wody $\mathrm{mg} / \mathrm{kg}$ max. & \multicolumn{3}{|c|}{500} & 200 & 200 & 200 \\
\hline $\begin{array}{c}\text { Zawartośc estrów metylowych } \\
\text { kwasów thuszczowych (FAME), } \\
\% \text { v/v. max. }\end{array}$ & \multicolumn{4}{|c|}{ - } & 5 & $\cdot$ \\
\hline $\begin{array}{c}\text { Zawartość zanieczyszczeń stałych } \\
\mathrm{mg} / \mathrm{kg} \max .\end{array}$ & \multicolumn{4}{|c|}{ wizualnie, nie zawiera } & 24 & 24 \\
\hline $\begin{array}{c}\text { Odporność na utlenianie } \\
\text { (zaw.osadów nierozp } . \mathrm{g} / \mathrm{cm}^{3} \text { ) max. }\end{array}$ & \multicolumn{3}{|c|}{25} & 10 & 25 & 25 \\
\hline $\begin{array}{l}\text { Smarność (skorygowana średnica } \\
\text { skazy zużycia } w 60^{\circ} \mathrm{C} \text { ) } \mu \mathrm{m} \text {. max. }\end{array}$ & & - & - & - & 460 & 460 \\
\hline
\end{tabular}

Tablica 8. Zestawienie ogólnych właściwości olejów napędowych w obowiązujących normach

Jak wynika $\mathrm{z}$ tablicy 8, olej ONM ma znacznie bardziej zaostrzone wymagania $w$ zakresie odporności na utlenianie oraz skłonności do koksowania $10 \%$ pozostałości podestylacyjnej w stosunku do wymagań określonych w obowiązującej normie europejskiej. Aktualna Norma Europejska z 2004 roku dopuszcza stosowanie biokomponentów typu estry metylowe kwasów tłuszczowych pochodzenia roślinnego FAME ("fatty acid methyl ester") w olejach napędowych. Przewiduje się, że nowa Polska Norma na oleje napędowe, będąca w opracowaniu określi ten sam dopuszczalny poziom stosowania biokomponentu typu FAME w tych paliwach.

\section{Podsumowanie}

Jak wynika z przedstawionych powyżej rozważań i danych zawartych $w$ tablicach, kryteria oceny jakości olejów napędowych ulegają poszerzeniu w zakresie ilości i zaostrzeniu, co do ich miar i wag. Tendencja ta wynika z dwu zasadniczych powodów:

Po pierwsze, nowoczesne silniki o zapłonie samoczynnym charakteryzują się znacznie bardziej zaostrzonymi warunkami pracy, co do liczby obrotów, uzyskiwanej mocy, przyspieszenia, masy, wielkości, stosowanych materiałów konstrukcyjnych itp. Przewiduje się, ze po 2007 roku średnie zużycie oleju napędowego wynosić będzie 2,5 1 na $100 \mathrm{~km}$ przebiegu. Taki kierunek rozwoju konstrukcji i parametrów eksploatacyjnych 
powodować będzie sukcesywne podwyższanie wymagań jakościowych w stosunku do olejów napędowych. Prawdopodobne będzie także poszukiwanie nowych metod badawczych w celu jeszcze dokładniejszego określenia możliwości olejów napędowych do racjonalnej ich reakcji na wymuszenia ze strony współczesnych i perspektywicznych konstrukcji silników.

Drugim, aktualnie ważniejszym powodem zaostrzania wymagań jakościowych w stosunku do olejów napędowych są zagadnienia ochrony środowiska naturalnego. Wykładniczo rosnąca, w niektórych krajach, ilość eksploatowanych samochodów, powoduje i powodować będzie zwiększenie wymagań co do składu i ilości składników spalin, co ma istotny związek $z$ kryteriami oceny jakości paliw i ich wielkością. Program "AUTO-OIL" przewiduje w niedalekiej przyszłości wartości emisji składników spalin określone w tablicy 9 [6].

\begin{tabular}{|c|c|c|}
\hline Składnik spalin & Do 2000 roku & Od 2005 roku \\
\hline $\mathrm{CO}$ & 0,64 & 0,5 \\
\hline Węglowodory $+\mathrm{NO}_{x}$ & 0,56 & 0,3 \\
\hline $\mathrm{NO}_{\mathrm{x}}$ & 0,5 & 0,25 \\
\hline Cząstki stałe & 0,05 & 0,025 \\
\hline
\end{tabular}

Tablica 9. Graniczne zawartości składników w spalinach z silników o zapłonie samoczynnym w $[\mathrm{g} / \mathrm{km}]$

Osiągnięcie takich wartości emisji składników spalin w Polsce, gdzie istnieje duża liczba eksploatowanych pojazdów przestarzałych konstrukcji i niewłaściwie eksploatowanych, wydaje się bardzo mało prawdopodobne. Rozporządzenie Ministra Ochrony Środowiska, Zasobów Naturalnych i Leśnictwa, z dnia 8 września 1998 roku, opublikowane w Dz. U. Nr 121, podaje dopuszczalne wartości emisji składników spalin z urządzeń zasilanych paliwami gazowymi, ciekłymi i stałymi, ale z wyłączeniem silników spalinowych i turbin gazowych.

Istotnym jest również fakt, że poziom technologii istniejący w większości polskich rafinerii, może nie pozwolić na produkowanie olejów napędowych spełniających wymagania stosownych Dyrektyw UE, co będzie miało istotne znaczenie dla polskiego przemysłu, obligatoryjnie zobowiązanego do przestrzegania tych Dyrektyww oraz Norm Europejskich jako kraju członkowskiego UE.

Jak wykazano $\mathrm{w}$ tablicach, zaostrzające się wymagania $\mathrm{z}$ zakresu jakości olejów napędowych, eksploatowanych szczególnie w warunkach komunikacji miejskiej, spowodowały powstanie specjalnych gatunków tych olejów. Należą do nich oleje tzw. "Eko", w tym oleje napędowe lekkie, Ekodiesel i Ekodiesel Plus, oraz Olej Napędowy Miejski "Standard", 
produkowane przez Petrochemię Płock S.A. W zakresie niektórych właściwości olej ONM, spełnia aktualne wymagania obowiązującej Normy Europejskiej EN 590:2004. Według danych z Petrochemii Płock S.A.[7], oddany do eksploatacji czwarty blok hydrorafinacji olejów napędowych umożliwia produkowanie $w$ tych zakładach olejów napędowych spełniających podstawowe wymagania Dyrektywy Unii Europejskiej. Porównanie wymagań i przewidywanych możliwości Petrochemii Płock S.A po 2005 roku, przedstawiono w tablicy 10.

\begin{tabular}{|c|c|c|c|c|}
\hline Właściwość: & \multicolumn{2}{|c|}{$\begin{array}{c}\text { Wymagania Dyrektywy } \\
\text { 98/70 EC }\end{array}$} & $\begin{array}{c}\text { Przewidywane moźliwości } \\
\text { Petrochemii Płock SA. }\end{array}$ \\
\hline Lata: & 2000 & 2005 & 2000 & 2005 \\
\hline Liczba cetanowa min. & 51,0 & & 54 & 57 \\
\hline Gestość $w 15^{\circ} \mathrm{C}, \mathrm{kg} / \mathrm{m}^{3}$, max. & 845 & & 840 & 835 \\
\hline $95 \%$ obj. destyluje do temp. ${ }^{\circ} \mathrm{C}$, max. & 360 & & 350 & 345 \\
\hline Zawartość WWA \% mas. max. & 11 & & 3 & 1 \\
\hline Zawartość siarki mg $/ \mathrm{kg}$ max. & 350 & 50 & 200 & 50 \\
\hline
\end{tabular}

Tablica 10. Porównanie podstawowych wymagań na oleje napędowe określonych Dyrektywą 98/70 EC, a przewidywanymi możliwościami technologicznymi Petrochemii Płock S.A.

Polska Norma na oleje napędowe, jest zgodna z normą EN 590 edytowaną w 1999 roku. Należy sądzić, że nowa Polska Norma, na oleje napędowe, która winna być w miarę szybko wprowadzona i uwzględniać powinna wymagania normy EN 590:2004, w tym w zakresie stosowania biokomponentów typu FAME lub nawet FAEE (fatty acid ethyl ester").

\section{Bibliografia}

[1] BACZEWSKI K., BIERNAT K., MACHEL M., 1993 - Leksykon, Paliwa, Oleje, Smary w Eksploatacji Samochodów, WKiŁ, Warszawa.

[2] BIERNAT K., 1983 - Materiaty Pędne $i$ Smary”, Wyd. WAT, Warszawa.

[3] MERKISZ J., 1999 - Wymagania stawiane paliwom silnikow'ym przez wspótczesne silniki spalinow'e, Mat. II Międzynarodowej Konferencji pt: „Rozwój technologii paliw w świetle Dyrektyw Europejskich i Narodowych Uregulowań Normatywnych" Warszawa.

[4] BIERNAT K., KARASZ Z., 1997 - Paliw'a plynne i ich użytkowanie, Wyd. SIMP, Warszawa.

[5] HENK P. M.SENGERS, R. Eric OLSEN, Emmanuelle D. FAURE-BIRCHEM, 1999 Performance Tests for Diesel Injector Fouling, Fuel Foaming, and Related Functional Benefits”, Mat. II Międzynarodowej Konferencji pt: „Rozwój technologii paliw w świetle Dyrektyw Europejskich i Narodowych Uregulowań Normatywnych" Warszawa.

[6] MACKOWSKI J. M., 1999 - The EU Directives on Fuels Quality: a look beyond year 2000, Mat. II Międzynarodowej Konferencji pt: „Rozwój technologii paliw w świetle Dyrektyw Europejskich i Narodowych Uregulowań Normatywnych" Warszawa. 
Wymagania i perspektynıy rozzooju jakości olejóto napędoùych przeznaczonych do eksploatacji...

17] Now'a jakość paliw' Petrochemii Ptock S.A. 1999 - Mat. II Międzynarodowej Konferencji pt: „Rozwój technologii paliw w świetle Dyrektyw Europejskich i Narodowych Uregulowań Normatywnych" Warszawa.

[8] BACZEWSKI K., KAEDOŃSKI T., 2004 - Paliwa do silników o zaptonie samoczynnym, WKiŁ, Warszawa.

\title{
„Requirements and perspectives of development of quality of diesel fuels used for exploitation especialy in urban traffic considering environmental protection"
}

\begin{abstract}
SUMMARY
Combustion of liquid fuels including diesel fuels is one of major process influating the condition of environment. Requirements of quality of diesel fueles is related with development of construction of fuel feed systems, combustion and exhaust gas systems and also with growing expectations from environmental protection. In article are shown basic connections between standarts of diesel fuels used in urban traffic described by proper norms and exploitational overworks and environmental expectations. Developmental tendencies of quality of those fuels are also mentioned.
\end{abstract}

